\title{
Patients with glycogen storage diseases undergoing anesthesia: a case series
}

\author{
Carmelina Gurrieri, Juraj Sprung, Toby N. Weingarten * (i) and Mary E. Warner
}

\begin{abstract}
Background: Glycogen storage diseases are rare genetic disorders of glycogen synthesis, degradation, or metabolism regulation. When these patients are subjected to anesthesia, perioperative complications can develop, including hypoglycemia, rhabdomyolysis, myoglobinuria, acute renal failure, and postoperative fatigue. The objective of this study was to describe the perioperative course of a cohort of patients with glycogen storage diseases.

Methods: This is a retrospective review of patients with glycogen storage diseases undergoing anesthetic care at our institution from January 1, 1990, through June 30, 2015 to assess perioperative management and outcomes.

Results: We identified 30 patients with a glycogen storage disease who underwent 41 procedures under anesthesia management. Intraoperative lactic acidosis developed during 4 major surgeries (3 liver transplants, 1 myectomy), and in all cases resolved within 24 postoperative hours. Lactated Ringer solution was used frequently. Preoperative and intraoperative hypoglycemia was noted in some patients with glycogen storage disease type I, all of which responded to administration of dextrose-containing solutions. No serious postoperative complications occurred.

Conclusions: Patients with glycogen storage disease, despite substantial comorbid conditions, tolerates the anesthetic management without major complications. Several patients who experienced self-limited metabolic acidosis were undergoing major surgical procedures, during which acidosis could be anticipated. Close monitoring and management of blood glucose levels of patients with glycogen storage disease type I is prudent.
\end{abstract}

Keywords: General anesthesia, Glycogen storage disease, Perioperative complications

\section{Background}

Glycogen storage diseases (GSDs) are disorders of the metabolism of glycogen which result from mutations in the genes involved in either the synthesis and degradation of glycogen or the regulation of glycogen metabolism. They have been categorized by number according to the recognition of the responsible enzyme defect [1]. The age at onset of disease varies from in utero to adulthood. Patients may have various clinical presentations, including exercise intolerance, myalgias, myoglobinuria, severe hypoglycemia, hepatomegaly, and cardiomyopathy. When subjected to anesthesia, these patients are at risk for the development of hypoglycemia, rhabdomyolysis, myoglobinuria, and acute renal failure [2-7]. The aim of this study was to characterize the perioperative course of patients with GSDs

\footnotetext{
* Correspondence: weingarten.toby@mayo.edu

Department of Anesthesiology and Perioperative Medicine, Mayo Clinic, 200 First St SW, Rochester, MN 55905, USA
}

who underwent anesthetic management at a single tertiary medical center.

\section{Methods}

This study was approved by the Mayo Clinic Institutional Review Board study, (Study ID 15-004738, approval date July 6, 2015, by Ellen Olson). Consistent with Minnesota Statute 144.335 , we included only patients who had provided authorization for research use of their medical records.

We searched our institutional patient database to identify the records of patients with GSDs who underwent surgeries or procedures with anesthetic management at Mayo Clinic, Rochester, Minnesota, between January 1, 1990, and June 31, 2015. The diagnosis of GSD was made through clinical signs and symptoms and was confirmed by muscle biopsy, liver biopsy, or genetic testing. For all patients identified, the records were reviewed for demographics, preexisting comorbid conditions, surgi$\mathrm{cal} /$ procedural records, anesthetic type and course, and 
type of fluids used intraoperatively. We also reviewed preoperative, intraoperative, and postoperative laboratory values, with particular attention to arterial $\mathrm{pH}$ and serum glucose, and lactate levels as potential markers of metabolic decompensation. Hypoglycemia was defined as blood glucose concentrations of $70 \mathrm{mg} / \mathrm{dL}$ or lower [8]; and metabolic acidosis was defined as $\mathrm{pH}$ imbalance due to a reduction in bicarbonate (HCO3-) of $22 \mathrm{mmol} / \mathrm{L}$ or lower, which was not a result from secondary causes, e.g., chronic respiratory alkalosis. In addition, we reviewed postoperative course and patient disposition (eg, admission to general medical unit or intensive care unit, or outpatient procedure) and any complications within 30 postoperative days. Demographics and perioperative characteristics were summarized using descriptive statistics.

\section{Results}

Our search of the database identified 30 patients with GSD who underwent 41 procedures under anesthesia management.

\section{Preoperative clinical characteristics}

Table 1 shows the clinical characteristics of patients with GSD, which varied depending on the specific disorder. Patients with type I disorder (von Gierke disease) primarily had metabolic disorders consisting of hypoglycemia. Patients with type II (Pompe disease) and type V (McArdle disease) often had myopathy and muscle weakness. Patients with type II disorder often had respiratory failure related to myopathy or muscle weakness and heart failure from hypertrophic cardiomyopathy. Two of these patients (\#13 and \#15) underwent preoperative Holter monitoring: sinus tachycardia (fastest heart rate, 137 beats/min) was detected in patient \#13, and ventricular tachycardia (fastest heart rate, 163 beats/min) was detected in patient \#15. Cardiac manifestations were also present in the patient with type 0 disorder. Patients with other types of GSD typically had muscle weakness, myopathy, or hepatosplenomegaly, or a combination of these.

\section{Anesthesia course and Intraoperative fluid administration} Case mix and anesthetic management is summarized in Table 2. Twenty-two procedures were outpatient based. Twenty-eight procedures were performed under general anesthesia, of which 23 were performed with endotracheal intubation and 5 with a laryngeal mask airway. The other 13 procedures were performed under monitored anesthesia care. Most patients underwent either diagnostic biopsies $(n=20)$ or minor procedures $(n=13)$ (e.g., dilation and curettage, reduction mammoplasty, gastric tube placement). The other patients $(n=8)$ underwent extensive operations: liver transplant $(n=3)$,
Table 1 Clinical characteristics of study patients with glycogen storage disease

\begin{tabular}{|c|c|c|}
\hline \multirow[b]{2}{*}{ Pt } & \multicolumn{2}{|l|}{ Clinical presentation } \\
\hline & Neurologic/Muscular & Other \\
\hline \multicolumn{3}{|c|}{ GSD type 0} \\
\hline 1 & Muscle weakness & $\begin{array}{l}\text { OSA; hypertrophic } \\
\text { cardiomyopathy; hypertension }\end{array}$ \\
\hline \multicolumn{3}{|c|}{ GSD type I (von Gierke) } \\
\hline 2 & $\begin{array}{l}\text { Muscle weakness; gait } \\
\text { abnormalities }\end{array}$ & $\begin{array}{l}\text { Lactic acidosis; hypoglycemia; } \\
\text { hepatic adenoma }\end{array}$ \\
\hline 3 & None reported & Hypoglycemia \\
\hline 4 & None reported & $\begin{array}{l}\text { Hypertension; hypoglycemia; } \\
\text { lactic acidosis }\end{array}$ \\
\hline 5 & Seizures & $\begin{array}{l}\text { Hyperuricemia; lactic acidosis; } \\
\text { hypoglycemia }\end{array}$ \\
\hline 6 & $\begin{array}{l}\text { Developmental delay; } \\
\text { velopharyngeal insufficiency }\end{array}$ & Hypoglycemia \\
\hline 7 & Fatigue, muscle weakness & Hypoglycemia \\
\hline \multicolumn{3}{|c|}{ GSD type II (Pompe) } \\
\hline 8 & $\begin{array}{l}\text { Severe scoliosis; muscle } \\
\text { weakness; wheelchair-bound }\end{array}$ & $\begin{array}{l}\text { Respiratory failure (BiPAP); } \\
\text { restricted lung disease }\end{array}$ \\
\hline 9 & Muscle weakness; hypotonia & None reported \\
\hline 10 & Muscle weakness & $\begin{array}{l}\text { Respiratory failure (BiPAP); } \\
\text { pulmonary hypertension; } \mathrm{CHF} \text {; } \\
\text { dilated cardiomyopathy; atrial } \\
\text { fibrillation }\end{array}$ \\
\hline 11 & Muscle weakness & None reported \\
\hline 12 & Muscle weakness & CHF; dilated cardiomyopathy \\
\hline 13 & Muscle weakness & Respiratory failure (BiPAP) \\
\hline 14 & Muscle weakness & Dyspnea; hypertension \\
\hline 15 & None reported & $\begin{array}{l}\text { Hypertrophic cardiomyopathy; } \\
\text { ventricular tachycardia }\end{array}$ \\
\hline
\end{tabular}

GSD type IV (Andersen)

16 Developmental delay Hepatosplenomegaly

GSD type $V$ (McArdle)

17 Muscle weakness; cervical None reported radiculopathy

18 Muscle stiffness; increased serum creatine kinase

19 Muscle weakness

20 Muscle weakness

21 Muscle cramps; exercise intolerance

22 Exercise intolerance

23 Muscle weakness

24 Muscle weakness and stiffness

25 Muscle weakness

26 Episodes of rhabdomyolysis; exercise intolerance

27 Muscle weakness

None reported

None reported

None reported

None reported

None reported

None reported

None reported

None reported

None reported

Hypertension

GSD type VI (Hers)

28 None reported

Lactic acidosis

GSD type VII (Tarui)

29 Muscle weakness None reported 
Table 1 Clinical characteristics of study patients with glycogen storage disease (Continued)

\begin{tabular}{|c|c|c|}
\hline \multirow[b]{2}{*}{$\mathrm{Pt}$} & \multicolumn{2}{|l|}{ Clinical presentation } \\
\hline & Neurologic/Muscular & Other \\
\hline \multicolumn{3}{|c|}{ Unidentified, likely glycolytic defect } \\
\hline 30 & Proximal muscle myopathy & Hypoglycemia \\
\hline
\end{tabular}

Abbreviations: BiPAP bilevel positive airway pressure, $C H F$ congestive heart failure, $G$ l gastrointestinal, $M H$ malignant hyperthermia, OSA obstructive sleep apnea, Pt patient

myectomy $(\mathrm{n}=1)$, Whipple procedure $(\mathrm{n}=1)$, and spinal fusion $(\mathrm{n}=3)$.

Nondepolarizing neuromuscular blocking drugs were administered in 16 patients, and succinylcholine was used in 3 , without adverse effects, including patients with Pompe disease and preexisting muscle weakness. Propofol infusions were used in 14 cases. Lactated Ringer's solution was used in 33 procedures (80\%), but patients with a history of hypoglycemia were intraoperatively administered dextrosecontaining solutions, including all patients with type I. Among patients with type I, 2 of them (\#2 and \#5) had hypoglycemia preoperatively and $3(\# 3, \# 4$, and \#15) had borderline low glucose levels (71-75 mg/dL). Patients \#2 and \#3 developed hypoglycemia during orthotopic liver transplant surgery (59 and $34 \mathrm{mg} / \mathrm{dL}$, respectively). Perioperative mild metabolic acidosis developed in 4 patients undergoing orthotopic liver transplant and myectomy, which resolved within 24 postoperative hours.

\section{Postoperative course}

No clinically significant postoperative complications occurred among the group (Table 2). There were no unexpected intensive care unit admissions, and all patients admitted to the intensive care unit were discharged to a regular postoperative ward within $24 \mathrm{~h}$.

\section{Discussion}

The most important observation of this study was that patients with GSDs, despite having substantial comorbid conditions, tolerated surgery and anesthesia without major complications. Self-limited, transient, metabolic acidosis developed in several patients undergoing major surgical procedures, during which it may be expected however, it remains unclear whether underlying metabolic disorder was a contributing factor. Another important observation was that hypoglycemia was present in some patients with GSD type I. In this subset of patients, it is prudent to use glucose-containing fluids and closely monitor glucose levels.

\section{GSD type I (von Gierke disease)}

Patients with type I are at increased risk for perioperative metabolic and homeostatic derangements, particularly hypoglycemia. These abnormalities are mainly
Table 2 Case mix, surgical and anesthetic characteristics in patients with glycogen storage disease

\begin{tabular}{|c|c|c|c|c|}
\hline Pt & $\begin{array}{l}\text { Age }^{a} \text { at } \\
\text { Surgery, y }\end{array}$ & $\begin{array}{l}\text { Surgery/Anesthesia } \\
\text { duration, min/Airway/ } \\
\text { Anesthetic Agents }\end{array}$ & Fluid used & Disposition \\
\hline \multicolumn{5}{|c|}{ GSD type 0} \\
\hline 1 & $51-60$ & Muscle biopsy/120,P & $L R$ & Outpatient \\
\hline \multicolumn{5}{|c|}{ GSD type I (Von Gierke) } \\
\hline 2 & $19-30$ & $\begin{array}{l}\text { Liver transplant/360/ } \\
\text { P, C, S, Iso }\end{array}$ & $\begin{array}{l}\text { NS; D5W; } \\
\text { PRBC; Cryo; } \\
\text { Albumin }\end{array}$ & $\mathrm{ICU}$ \\
\hline 3 & $11-18$ & $\begin{array}{l}\text { Liver transplant/300/ } \\
\text { P, C, Iso }\end{array}$ & $\begin{array}{l}\text { NS; D5W; } \\
\text { Albumin }\end{array}$ & $\mathrm{ICU}$ \\
\hline 4 & $6-10$ & $\begin{array}{l}\text { Liver transplant/330/ } \\
P, V \text {, Iso }\end{array}$ & $\begin{array}{l}\text { NS; D5NS; } \\
\text { PRBC; Albumin }\end{array}$ & $\mathrm{ICU}$ \\
\hline \multirow[t]{2}{*}{5} & $1-2$ & $\begin{array}{l}\text { Muscle biopsy/120/ } \\
\text { Sev, } \mathrm{N}_{2} \mathrm{O}\end{array}$ & D5NS & Outpatient \\
\hline & $1-2$ & $\begin{array}{l}\text { Gastric tube placement/60/ } \\
\text { P, At, Iso }\end{array}$ & D10NS & Ward \\
\hline \multirow[t]{3}{*}{6} & $<1$ & $\begin{array}{l}\text { Gastric tube placement/ } \\
\text { 100/P, At, Sev }\end{array}$ & LR; D10NS & Ward \\
\hline & $3-5$ & Tonsillectomy/110/P, V & LR; D10NS & Ward \\
\hline & $3-5$ & Myringotomy/ 100/P & LR; D10NS & Ward \\
\hline 7 & $11-18$ & $\begin{array}{l}\text { Rectal abscess I\&D/70/ } \\
\text { At, STP, } \mathrm{N}_{2} \mathrm{O}\end{array}$ & D10W & Outpatient \\
\hline & $11-18$ & Abscess I\&D/120/P, At, $\mathrm{N}_{2} \mathrm{O}$ & LR; D10W & Outpatient \\
\hline \multicolumn{5}{|c|}{ GSD type II (Pompe) } \\
\hline \multirow[t]{2}{*}{8} & $11-18$ & $\begin{array}{l}\text { Anterior spinal fusion/300/ } \\
\text { STP, Iso, Sev, P }\end{array}$ & $\begin{array}{l}\text { LR; PRBC; FFP; } \\
\text { Platelets; } \\
\text { Hetastarch; } \\
\text { Albumin }\end{array}$ & ICU \\
\hline & $11-18$ & $\begin{array}{l}\text { Posterior spinal fusion/730/ } \\
\mathrm{P}, \mathrm{Sev}, \mathrm{N}_{2} \mathrm{O}\end{array}$ & $L R$ & $\mathrm{ICU}$ \\
\hline 9 & $<1$ & Muscle biopsy/75/P, $\mathrm{N}_{2} \mathrm{O}$ & LR & Outpatient \\
\hline \multirow[t]{2}{*}{10} & $41-50$ & Muscle biopsy/MAC/60, P & LR; NS & Ward \\
\hline & $41-50$ & Tracheostomy/80/E, S, Sev & $L R$ & $\mathrm{ICU}$ \\
\hline 11 & $51-60$ & $\begin{array}{l}\text { Muscle biopsy/MAC/ } \\
90 \text { mask, P }\end{array}$ & NS & Outpatient \\
\hline \multirow[t]{2}{*}{12} & $31-40$ & $\begin{array}{l}\text { Myocardial biopsy/MAC/ } \\
90, \mathrm{Mz}, \mathrm{AL}\end{array}$ & $L R$ & Outpatient \\
\hline & $31-40$ & $\begin{array}{l}\text { Parathyroidectomy/120/ } \\
\text { E, V, Iso }\end{array}$ & $L R$ & Ward \\
\hline 13 & $41-50$ & Muscle biopsy/MAC/60,P & $L R$ & ICU \\
\hline 14 & $41-50$ & $\begin{array}{l}\text { Muscle biopsy/MAC/120/ } \\
\text { Mask, P }\end{array}$ & $\begin{array}{l}\text { NS; LR; } \\
\text { Albumin }\end{array}$ & Outpatient \\
\hline \multirow[t]{2}{*}{15} & $3-5$ & $\begin{array}{l}\text { Myectomy (ICD)/ CPB/ } \\
280, \text { Sev, V, Iso }\end{array}$ & $L R$ & $\mathrm{ICU}$ \\
\hline & $3-5$ & $\begin{array}{l}\text { Sternal wire removal/180/E, } \\
\text { RO, Sev }\end{array}$ & & Ward \\
\hline \multicolumn{5}{|c|}{ Glycogen storage disease type IV (Andersen) } \\
\hline \multirow[t]{2}{*}{16} & $1-2$ & $\begin{array}{l}\text { Liver biopsy/MAC/60/ } \\
\text { Mask, Sev }\end{array}$ & $L R$ & Outpatient \\
\hline & $1-2$ & $\begin{array}{l}\text { Myringotomy/GA/60/ } \\
\text { Sev, } \mathrm{N}_{2} \mathrm{O}\end{array}$ & None & Outpatient \\
\hline 17 & $61-70$ & $\begin{array}{l}\text { Cervical discectomy/ } \\
200, P, R O\end{array}$ & & Ward \\
\hline
\end{tabular}

Glycogen storage disease type $\mathrm{V}$ (McArdle) 
Table 2 Case mix, surgical and anesthetic characteristics in patients with glycogen storage disease (Continued)

\begin{tabular}{|c|c|c|c|c|}
\hline $\mathrm{Pt}$ & $\begin{array}{l}\text { Age }^{a} \text { at } \\
\text { Surgery, y }\end{array}$ & $\begin{array}{l}\text { Surgery/Anesthesia } \\
\text { duration, min/Airway/ } \\
\text { Anesthetic Agents }\end{array}$ & Fluid used & Disposition \\
\hline 18 & $11-18$ & $\begin{array}{l}\text { Muscle biopsy/60)/ LMA/ } \\
\text { Sev, } \mathrm{N}_{2} \mathrm{O}\end{array}$ & $L R$ & Outpatient \\
\hline 19 & $6-10$ & $\begin{array}{l}\text { Muscle biopsy/60/P, } \\
\text { Sev, } \mathrm{N}_{2} \mathrm{O}\end{array}$ & $L R$ & Outpatient \\
\hline 20 & $41-50$ & $\begin{array}{l}\text { Whipple /GA /360/ } \\
\text { P, S, V, Iso }\end{array}$ & $L R$ & Ward \\
\hline 21 & $41-50$ & $\begin{array}{l}\text { Muscle biopsy/MAC/60/ } \\
\text { Mask/P }\end{array}$ & $L R$ & Outpatient \\
\hline 22 & $11-18$ & $\begin{array}{l}\text { Muscle biopsy/MAC/90/ } \\
\text { Mask/P, Sev }\end{array}$ & $L R$ & Outpatient \\
\hline 23 & $19-30$ & $\begin{array}{l}\text { Muscle biopsy/ MAC/105/ } \\
\text { Mask, P }\end{array}$ & $L R$ & Outpatient \\
\hline 24 & 19-30 & $\begin{array}{l}\text { Muscle biopsy/ MAC/60/ } \\
\text { Mask, P }\end{array}$ & $L R$ & Outpatient \\
\hline 25 & $6-10$ & Muscle biopsy/70/ LMA, P & $L R$ & Outpatient \\
\hline 26 & $19-30$ & $\begin{array}{l}\text { Muscle biopsy/ MAC/120/ } \\
\text { Mask, P }\end{array}$ & $L R$ & Outpatient \\
\hline 27 & $>70$ & $\begin{array}{l}\text { Muscle biopsy/MAC/60/ } \\
\text { Mask, P }\end{array}$ & $L R$ & Outpatient \\
\hline \multicolumn{5}{|c|}{ GSD type VI (Hers) } \\
\hline 28 & $1-2$ & Liver biopsy/105/Sev, RO & D5NS & Outpatient \\
\hline \multicolumn{5}{|c|}{ GSD type VII (Tarui) } \\
\hline 29 & $61-70$ & $\begin{array}{l}\text { Muscle biopsy/MAC/210/ } \\
\text { Mask, P }\end{array}$ & $L R$ & Outpatient \\
\hline \multicolumn{5}{|c|}{ Unidentified, likely glycolytic defect } \\
\hline \multirow[t]{3}{*}{30} & $31-40$ & $\begin{array}{l}\text { Dilation \& curettage/60/ } \\
\text { LMA/P, } \mathrm{N}_{2} \mathrm{O}\end{array}$ & LR & Outpatient \\
\hline & $31-40$ & $\begin{array}{l}\text { Mammoplasty/240/ } \\
\mathrm{P}, \mathrm{V}, \mathrm{N}_{2} \mathrm{O}\end{array}$ & $L R$ & Ward \\
\hline & $31-40$ & $\begin{array}{l}\text { Breast hematoma } \\
\text { evacuation/90/LMA/P, } \mathrm{N}_{2} \mathrm{O}\end{array}$ & $L R$ & Ward \\
\hline
\end{tabular}

Abbreviations: At atracurium, BiPAP bilevel positive airway pressure, $C$ cisatracurium, $C P B$ cardiopulmonary bypass, D10NS 10\% dextrose with $0.9 \%$ normal saline, D10W $10 \%$ dextrose with water, D5NS $5 \%$ dextrose with $0.9 \%$ normal saline, $D 5 W 5 \%$ dextrose with water, $E$ etomidate, $F$ female, GA general anesthesia, ICD implantable cardioverter-defibrillator; ICU intensive care unit, I\&D incision and drainage, Iso isoflurane, $L M A$ laryngeal mask airway, $M$ male, $M z$ midazolam, $M A C$ monitored anesthesia care, $N_{2} \mathrm{O}$ nitrous oxide, NA not available, NS $0.9 \%$ normal saline, $P$ propofol, $P R B C$ packed red blood cells transfusion, $P$ t patient, $R O$ rocuronium, $S$ succinylcholine, Sev sevoflurane, STP sodium thiopental, $V$ vecuronium

${ }^{a} \mathrm{Age}$ is reported as a range (in year): $<1$ year; $1-2 ; 3-5 ; 6-10 ; 11-18 ; 19-30$; $31-40 ; 41-50 ; 51-60 ; 61-70$; $>70$

related to a defect of either glucose-6-phosphatase or glucose-6-phosphatase transporter, which impairs the production of glucose via either gluconeogenesis or glycogenosis. Accordingly, frequent monitoring of blood glucose is recommended during the perioperative period $[1,9-11]$ especially during major procedures. In our series, patients with hypoglycemia were administered dextrose-containing solutions during their procedures. Patient \#4 had intraoperative hypoglycemia $(34 \mathrm{mg} / \mathrm{dL}$ ), he received a dextrose solution infusion, and all subsequent glucose checks were above $100 \mathrm{mg} / \mathrm{dL}$. This patient underwent liver transplant, which in itself can contribute the glucose metabolism impairment and can potentially cause hypoglycemia. Patients with type I disease are also prone to the development of organic acidemias; in this series, the 3 patients who underwent liver transplant were known to have lactic acidosis (patients \#2, \#3, and \#4). Lactate ringer solution (LR) was used for 7 minor procedures without incident, albeit in patients without known organic acidemias, and in conjunction with dextrose-containing solutions.

Patients with type I are also at risk for the development of pancreatitis secondary to hypertriglyceridemia $[1,12]$. Bustamante and Appachi [11] reported a case of pancreatitis in a 4-year-old girl with type I undergoing general anesthesia for tonsillectomy with propofol infusion. In our series, the 3 patients undergoing liver transplant received propofol infusion as a part of their anesthetic, with an average of $12 \mathrm{~h}$ ' duration, withoutadverse effects. Patient with GDS type I may also have coagulation abnormalities arising from acquired von Willebrand factor abnormalities, and the perioperative use of desmopressin advocated to facilitate hemostasis $[13,14]$. However, in our cohort the perioperative records did not indicate coagulopathy.

\section{GSD type II (Pompe disease)}

Patients with type II may have marked hypertrophic cardiomyopathy and an increased risk of dysrhythmia [15, 16]. Cases of intraoperative cardiac arrest have been described $[17,18]$. Therefore, preoperative electrocardiography and echocardiography should be considered to assess both cardiac rhythm and function. Wang [15] described ventricular and supraventricular dysrhythmias in 9 infants with type II disease soon after the induction of general anesthesia with propofol and/or sevoflurane. Two of these patients died intraoperatively as a result of dysrhythmias. In our series, preoperative electrocardiography was performed in most patients with Pompe disease, and 2 of our patients (\#13 and \#15) undergoing muscle biopsy and septal myectomy had preoperative echocardiography and Holter monitoring. No perioperative dysrhythmias were noted in this subset of patients.

Type II disease is also known for skeletal muscle myopathies. These may lead to weakness of the respiratory muscles, which further leads to chronic respiratory failure [19] and increased risk of postoperative respiratory complications [20]. Indeed, 4 of our patients (\#8, \#10,\#13, and \#14) had known respiratory symptoms preoperatively. One patient (\#10) underwent elective tracheostomy for management of chronic hypercarbic respiratory failure. Fortunately, none of our patients had acute worsening of respiratory symptoms postoperatively. Muscle relaxation with nondepolarizing agents should be used cautiously because residual weakness 
could be poorly tolerated. However, these drugs were used in 3 cases $(\# 10, \# 12$, and \#15) without incident.

\section{GSD type $\mathrm{V}$ (McArdle disease)}

Patients with type $\mathrm{V}$ disease may have rhabdomyolysis, myoglobinuria, and acute renal failure [2]. Cases of acute renal failure have been reported after strenuous or vigorous exercise [3, 4] and after an asthmatic attack [5]. Cases of massive rhabdomyolysis and myoglobinuria also have been observed after a diagnostic forearm ischemic work test using a tourniquet [2, 21]. Indeed, particular attention should be paid to intraoperative positioning because improper positioning can increase the risk of rhabdomyolysis. In our series, most patients with type $\mathrm{V}$ had a chronically high creatine kinase level, but patients had no abnormal temperature fluctuations, signs of hypermetabolism, or signs of rhabdomyolysis in the perioperative period. In this study, potential malignant hyperthermia triggers-volatile anesthetics and succinylcholine-were used in 4 cases (\#18, \#19, \#20, and \#22) with no clinical complications observed. Despite reported suspected cases of malignant hyperthermia in the type $\mathrm{V}$ disease $[2,22,23]$, the U.S. Malignant Hyperthermia Association has stated that there is no association between any type of GSD and malignant hyperthermia [24].

\section{GSD type 0 , IV, VI, and VII}

To our knowledge, there are no reported cases of patients with type $0, \mathrm{IV}, \mathrm{VI}$, or VII undergoing anesthesia who had perioperative complications related to their disease. It is known that types 0 , IV, and VI affect the liver and that patients might experience mild hypoglycemia, whereas type VII primarily affects the muscle, which results in muscle weakness and myalgia. Any potential challenges related to anesthesia care in these patients are still uncertain. In our case series, the 4 patients with type IV, VI, VII, and 0 (\#16, \#28, \#29 and \#30, respectively), who underwent liver biopsy in the first 2 cases and muscle biopsy in the other 2, tolerated anesthesia well with no major perioperative complications. They were discharged the day of surgery. Because of the lack of previous reports and the limitations of our case series, no definitive recommendations can be made regarding anesthesia with these 4 GSD types. Further larger studies are warranted.

\section{Limitations}

This study has all the inherent limitations of a retrospective study design. Moreover in our cohort none of the patients included in the study underwent regional anesthesia, thus our experience with anesthetic technique is limited.

\section{Conclusions}

In our study, patients with various types of GSD undergoing anesthesia did not experience complications that could be attributed to anesthesia, per se. Hypoglycemia must be prevented in patients with type I (von Gierke disease), and thorough assessment of cardiac and pulmonary function is needed in type II (Pompe disease). Patients with type I (von Gierke disease) are also prone to the development of organic acidemias, but we did not encounter severe acid-base disturbances despite intraoperative administration of LR in some patients.

Abbreviations

GSD: Glycogen storage disease; LR: Lactated Ringer solution

\section{Acknowledgements \\ None. \\ Funding \\ Support for this manuscript was solely provided through the Department of Anesthesiology and Perioperative Medicine, Mayo Clinic, Rochester, \\ Minnesota.}

\section{Availability of data and materials \\ Available upon reasonable request.}

\section{Authors' contributions}

CG: data abstraction, data analysis, and writing the manuscript. JS: study design, data analysis, and writing the manuscript. TNW: study design, data abstraction, data analysis, and writing the manuscript. MEW: study design, data analysis, and writing the manuscript. All authors read and approved the final manuscript.

Ethics approval and consent to participate

The Mayo Clinic Institutional Review Board approved this study (Study ID 15-004738, approval date July 6, 2015, by Ellen Olson). Consistent with Minnesota Statute 144.335, only patients who had provided authorization for research use of their medical records were included.

\section{Consent for publication}

Consistent with Minnesota Statute 144.335, only patients who had provided authorization for research use of their medical records were included.

Competing interests

The authors declare that they have no competing interests.

\section{Publisher's Note}

Springer Nature remains neutral with regard to jurisdictional claims in published maps and institutional affiliations.

Received: 12 May 2017 Accepted: 2 October 2017

Published online: 06 October 2017

\section{References}

1. Burda P, Hochuli M. Hepatic glycogen storage disorders: what have we learned in recent years? Curr Opin Clin Nutr Metab Care. 2015;18(4):415-21.

2. Bollig G, Mohr S, Raeder J. McArdle's disease and anaesthesia: case reports. Review of potential problems and association with malignant hyperthermia. Acta Anaesthesiol Scand. 2005;49(8):1077-83.

3. Stamos GE, Crouch TT, Wood WG, Sharma JN. Acute renal failure in McArdle's disease. South Med J. 1979;72(1):77-9.

4. McMillan MA, Hallworth MJ, Doyle D, Douglas Briggs J, Junor BJR. Acute renal failure due to McArdle's disease. Ren Fail. 1989;11(1):23-5.

5. Tsushima K, Koyama S, Ueno M, Fujimoto K, Ichiyoshi T, Takei Y, Hanyu N, Kubo K. Rhabdomyolysis triggered by an asthmatic attack in a patient with McArdle disease. Intern Med. 2001;40(2):131-4. 
6. Davis PJ, Brandom BW. The association of malignant hyperthermia and unusual disease: when you're hot you're hot or maybe not. Anesth Analg. 2009;109(4):1001-3. Erratum in: Anesth Analg. 2009;109(6):2007

7. Reid CJ, Hebert D. Acute renal failure complicating liver transplantation in twin sisters with glycogen storage disease type la. Transplant Proc. 1996; 28(6):3629-31.

8. Workgroup on Hypoglycemia, American Diabetes Association. Defining and reporting hypoglycemia in diabetes: a report from the American Diabetes Association Workgroup on Hypoglycemia. Diabetes Care. 2005;28(5):1245-9.

9. Yu X, Huang Y, Du J. Bispectral index may not reflect the depth of anaesthesia in a patient with glycogen storage disease type I. Br J Anaesth. 2009;103(4):616.

10. Bevan JC. Anaesthesia in von Gierke's disease: current approach to management. Anaesthesia. 1980;35(7):699-702.

11. Bustamante SE, Appachi E. Acute pancreatitis after anesthesia with propofol in a child with glycogen storage disease type IA. Paediatr Anaesth. 2006; 16(6):680-3.

12. Derks TG, van Rijn M. Lipids in hepatic glycogen storage diseases: pathophysiology, monitoring of dietary management and future directions. J Inherit Metab Dis. 2015;38(3):537-43.

13. Mühlhausen C, Schneppenheim R, Budde U, Merkel M, Muschol N, Ullrich K, Santer R. Decreased plasma concentration of von Willebrand factor antigen (MWF:Ag) in patients with glycogen storage disease type la. J Inherit Metab Dis. 2005;28(6):945-50

14. Mollet-Boudjemline A, Hubert-Buron A, Boyer-Neumann C, Aldea R, Franco D, Trioche-Eberschweiller P, Mas AE, Mabille M, Labrune P, Gajdos V. Perioperative management of hemostasis for surgery of benign hepatic adenomas in patients with glycogen storage disease type ia. JIMD Rep. 2011;1:97-106

15. Wang LY, Ross AK, Li JS, Dearmey SM, Mackey JF, Worden M, Corzo D, Morgan C, Kishnani PS. Cardiac arrhythmias following anesthesia induction in infantile-onset Pompe disease: a case series. Paediatr Anaesth. 2007;17(8): 738-48.

16. Mori M, Bailey LA, Estrada J, Rehder CW, Li JS, Rogers JG, Bali DS, Buckley AF, Kishnani PS. Severe cardiomyopathy as the isolated presenting feature in an adult with late-Onset Pompe disease: a case report. JIMD Rep. 2017; 31:79-83.

17. Ellis FR. Inherited muscle disease. Br J Anaesth. 1980;52(2):153-64.

18. McFarlane HJ, Soni N. Pompe's disease and anaesthesia. Anaesthesia. 1986; 41(12):1219-24.

19. Gitlin MC, Jahr JS, Garth KL, Grogono AW. Ureteroscopic removal of left ureteral lithiasis in a patient with acid maltase deficiency disease. Anesth Analg. 1993;76(3):662-4.

20. Kotani N, Hashimoto H, Hirota K, Muraoka M, Matsuki A. Prolonged respiratory depression after anesthesia for parathyroidectomy in a patient with juvenile type of acid maltase deficiency. J Clin Anesth. 1996;8(7):620.

21. Meinck HM, Goebel HH, Rumpf KW, Kaiser H, Neumann P. The forearm ischaemic work test: hazardous to McArdle patients? I Neurol Neurosurg Psychiatry. 1982;45(12):1144-6.

22. Isaacs H, Badenhorst ME, Du Sautoy C. Myophosphorylase B deficiency and malignant hyperthermia. Muscle Nerve. 1989;12(3):203-5.

23. Lobato EB, Janelle GM, Urdaneta F, Malias MA. Noncardiogenic pulmonary edema and rhabdomyolsis after protamine administration in a patient with unrecognized McArdle's disease. Anesthesiology. 1999;91(1):303-5.

24. Malignant Hyperthermia Association of the United States. Malignant hyperthermia susceptibility and associated conditions. http://www.mhaus. org/healthcare-professionals/be-prepared/associated-conditions. Accessed 10 May 2017.

\section{Submit your next manuscript to BioMed Central and we will help you at every step:}

- We accept pre-submission inquiries

- Our selector tool helps you to find the most relevant journal

- We provide round the clock customer support

- Convenient online submission

- Thorough peer review

- Inclusion in PubMed and all major indexing services

- Maximum visibility for your research

Submit your manuscript at www.biomedcentral.com/submit 